\title{
Sistem Keamanan Ruangan Berbasis Internet Of Things Dengan Menggunakan Aplikasi Android
}

\author{
Kristomson $\mathrm{H}^{1}$, Rosalia H Subrata ${ }^{1}$, Ferrianto Gozali ${ }^{1}$
}

\begin{abstract}
Along with the increasing level of criminal data theft that occurs, a good room security system is needed to maintain data security of a particular agency or organization. A good security system is a security system that can be monitored and controlled over long distances using the internet or better known as IoT (Internet of Things). In this thesis, an IoT-based room security system will be designed using an Android application, this system works using several modules including RFID (Radio Frequency Identification) module, camera module and solenoid door lock. RFID cards in the RFID Module function as a process of identifying people who want to enter the room. In addition, this RFID module functions also as a trigger for the camera to work and taking pictures of people who want to enter the room. Data obtained from both modules will be sent to the Android application. The admin of the room can carry out a verification process to allow or reject the person who wants to enter the room. The results of the testing of this system can run well when the internet speed of the access point runs fast and stable, but it is less optimal when the internet speed of the access point runs slowly.

KEYWORDS: IoT, Android, Arduino
\end{abstract}

\begin{abstract}
ABSTRAK: Seiring dengan meningkatnya tingkat kriminal pencurian data yang terjadi maka dibutuhkan suatu sistem keamanan ruangan yang baik untuk menjaga keamanan data suatu instansi atau organisasi tertentu. Suatu sistem keamanan yang baik adalah sistem kemanan yang bisa di pantau dan di kendalikan dengan jarak yang jauh dengan menggunakan internet atau yang lebih dikenal dengan IoT (Internet of Things). Dalam skripsi ini akan dirancang suatu sistem kemanan ruangan berbasis IoT dengan menggunakan aplikasi Android, sistem ini bekerja menggunakan beberapa module diantaranya module RFID (Radio Frequency Identification), module kamera dan solenoid door lock. Kartu RFID pada Module RFID ini berfungsi sebagai proses identifikasi orang yang ingin masuk ke dalam ruangan. Selain itu module RFID ini juga berfungsi sebagai pemicu kamera untuk bekerja mengambil gambar orang yang ingin masuk ke dalam ruangan tersebut. Data yang diperoleh dari kedua module tersebut nantinya akan dikirimkan ke dalam aplikasi Android. Admin dari ruangan tersebut dapat melakukan proses verifikasi untuk mengizinkan atau menolak orang yang ingin memasuki ruangan tersebut. Hasil dari pengujian sistem ini dapat berjalan dengan baik ketika kecepatan internet dari akses point berjalan dengan cepat dan stabil, tetapi kurang optimal ketika kecepatan internet dari akses point berjalan dengan lambat.
\end{abstract}

KATA KUNCI: IoT, Android, Arduino

\section{PENDAHULUAN}

$\mathrm{D}$ efinisi sistem keamanan pada umumnya adalah untuk mengamankan suatu objek yang dimana objek itu berisi hal-hal penting untuk diamankan seperti rumah, ruangan, gedung ataupun hal lainnya. Sistem keamanan sangat diperlukan untuk mencegah tindak kejahatan pencurian atau tindak kejahatan kriminal lainnya, hal ini dibuat untuk mencegah tingkat kejahatan pencurian yang meningkat dari tahun ke tahun.

Pada penelitian ini sistem keamanan yang dibuat adalah sistem kemanan yang akan diimplementasikan pada ruang server, sebagaimana yang kita ketahui ruang server adalah suatu ruangan tempat penyimpanan datadata penting dari suatu instansi atau organisasi tertentu. Sistem keamanan ini digunakan untuk mengawasi orang yang ingin masuk kedalam ruangan tersebut untuk mencegah hal-hal yang tidak diinginkan seperti pencurian data ataupun manipulasi data. Sistem ini dibuat dengan menggunakan RFID (Radio Frequency Identification), kamera sebagai media pengawas dan aplikasi Android sebagai pengendali hak akses masuk ke dalam ruangan tersebut yang berbasis Internet of Things. Kelebihan dari sistem ini adalah sistem ini mampu mengawasi orang yang ingin masuk kedalam ruangan serta mampu mengendalikan sistem pengunci pintu yang berfungsi untuk membatasi orang yang masuk kedalam ruangan tersebut.

\section{METODE PENELITIAN}

Pada pembahasan rancangan sistem keamanan ruangan berbasis Internet of Things dengan menggunakan aplikasi Android ini metode penelitian yang digunakan adalah metode deskriptif, dimana penelitian ini berdasarkan fenomena yang terjadi saat ini.

Hal yang pertama dalam rancangan sistem keamanan ruangan berbasis Internet of Things dengan menggunakan aplikasi Android ini adalah pemasangan komponen perangkat keras dari sistem keamanan ini. Komponen yang pertama dirancang adalah RFID, RFID berfungsi sebagai izin masuk ruangan dari si pemilik kartu RFID tersebut dan setelah itu melakukan pemasangan kamera yang berfungsi untuk mengambil gambar dari orang yang masuk ke dalam ruangan tersebut lalu setelah itu pemasangan arduino yang berfungsi sebagai processing dari setiap komponen-komponen perangkat keras yang telah terpasang. Setelah tahap perancangan komponen perangkat keras selesai, langkah selanjutnya adalah tahap perancangan perangkat lunak database yang bertujuan untuk tempat penyimpanan data identitas dari si pemilik kartu RFID tersebut dan selanjutnya perancangan aplikasi Android yang berfungsi sebagai notifikasi kepada admin atau pemilik ruangan tersebut. Lalu setelah itu dilakukan tahap pengujian komponen dari sistem keamanan tersebut untuk memastikan bahwa komponen sudah berjalan sesuai dengan konsep perancangan. cara kerja sistem dapat dilihat pada Gambar 1 . berikut.

\footnotetext{
${ }^{1}$ Jurusan Teknik Elektro Fakultas Teknologi Industri Universitas Trisakti
} 


\section{Flowchart dan Diagram Sistem}

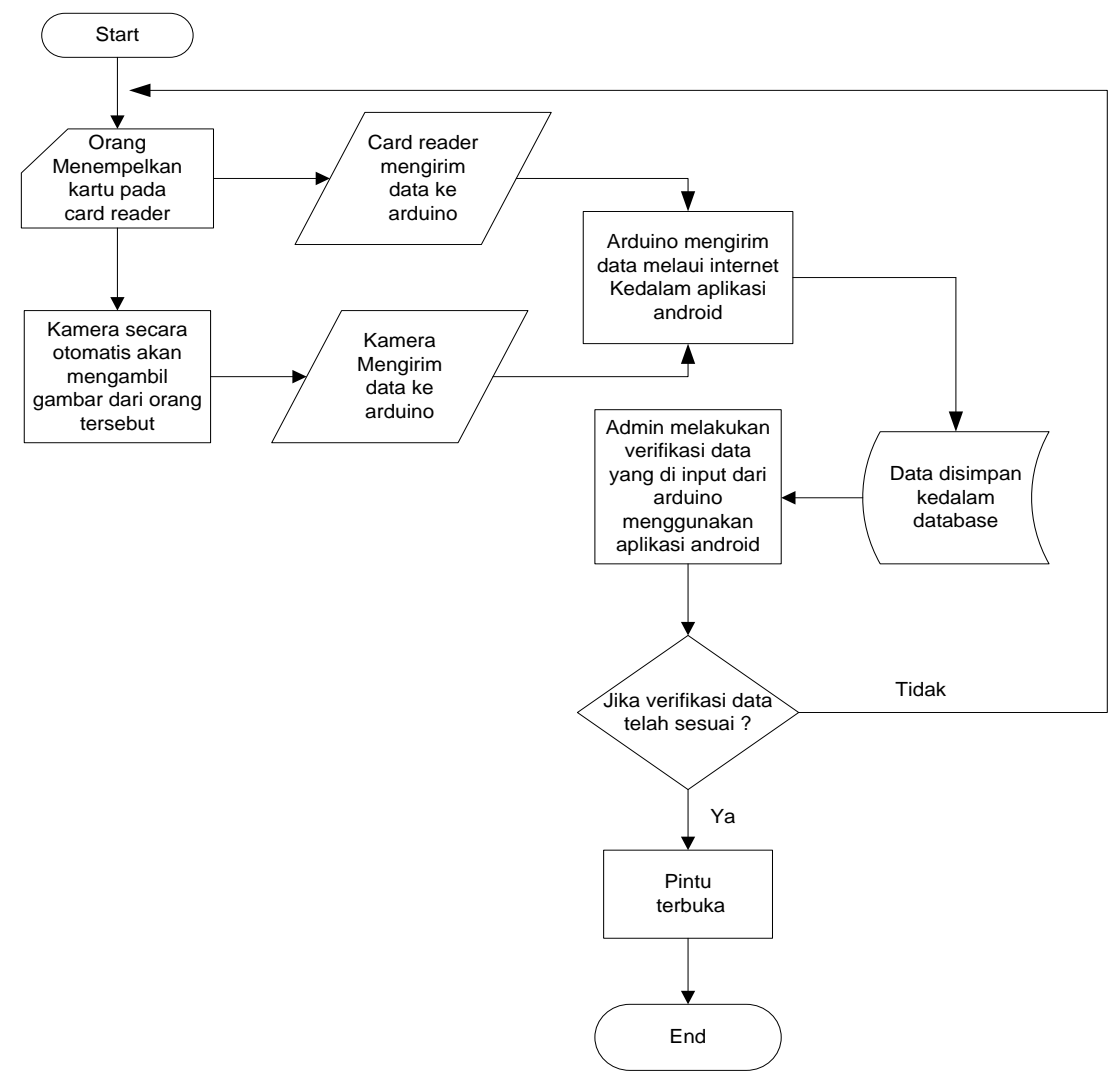

- Gambar 1. Flowchart Cara kerja sistem pada client

Cara kerja dari sistem ini adalah ditujukan untuk client yang ingin masuk ke dalam ruangan ketika orang masuk menggunakan kartu yang ditempelkan pada card reader RFID maka secara otomatis card reader RFID memberikan perintah kepada arduino untuk mengambil gambar orang yang ingin masuk ke dalam ruangan tersebut melalui kamera yang terletak di sisi pintu bagian atas. Setelah gambar diambil maka arduino akan memproses data dari kartu dan gambar orang tersebut, lalu mengirimkan data tersebut kedalam aplikasi Android dan secara bersamaan arduino juga mengirimkan notifikasi ke dalam aplikasi Android untuk proses verifikasi data yang dilakukan oleh admin dari ruangan tersebut. Di dalam notifikasi aplikasi Android tersebut terdiri dari nama, nomor identitas, nomor kartu dan gambar dari orang yang ingin masuk ke dalam ruangan tersebut lalu di dalam aplikasi, admin berhak untuk memberikan izin akses ataupun menolak izin akses orang tersebut untuk masuk ke dalam ruangan. Setelah data gambar dan data RFID diterima admin dapat memasukkan data tersebut kedalam database.

Namun pada akses masuk admin akan ditambahkan suatu keypad yang terletak di depan pintu ruangan, dimana keypad ini berfungsi sebagai kata sandi ketika internet dalam keadaan mati sehingga menyebabkan proses verifikasi data gagal seperti terlihat pada gambar.2. dan gambar 3. Kata sandi ini nantinya yang akan digunakan sebagai proses untuk masuk ke dalam ruangan pada saat internet mati dan hanya diketahui oleh admin dari ruangan tersebut. 


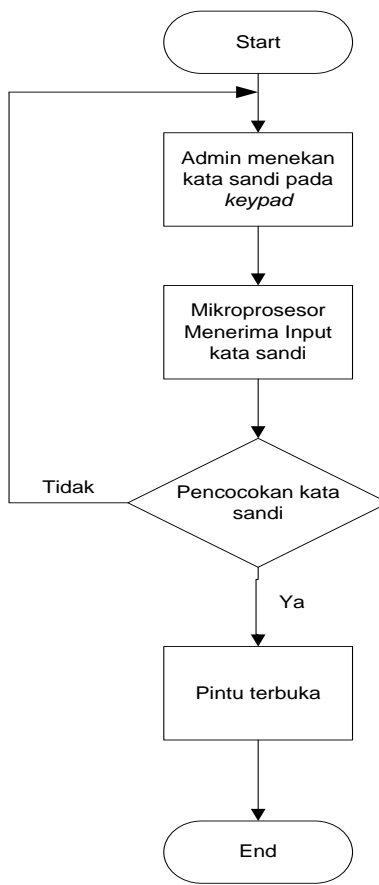

- Gambar 2. Flowchart Cara kerja sistem pada admin

\section{Interkoneksi}

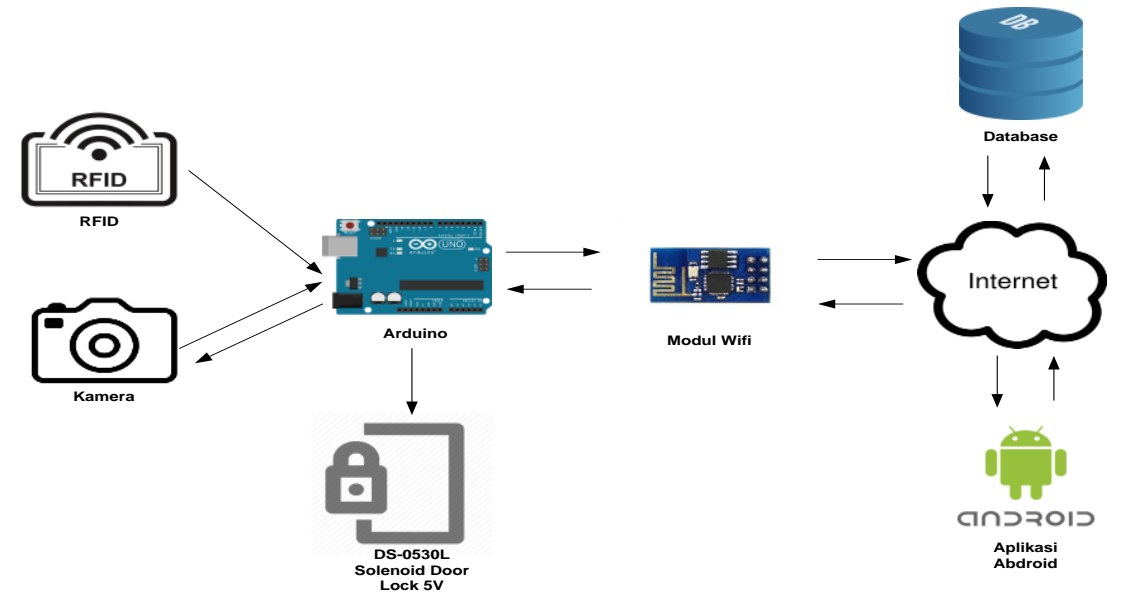

- Gambar 3. Diagram blok Sistem

Jaringan interkoneksi yang digunakan adalah Internet (Interconnection Networking) Seperti pada Gambar

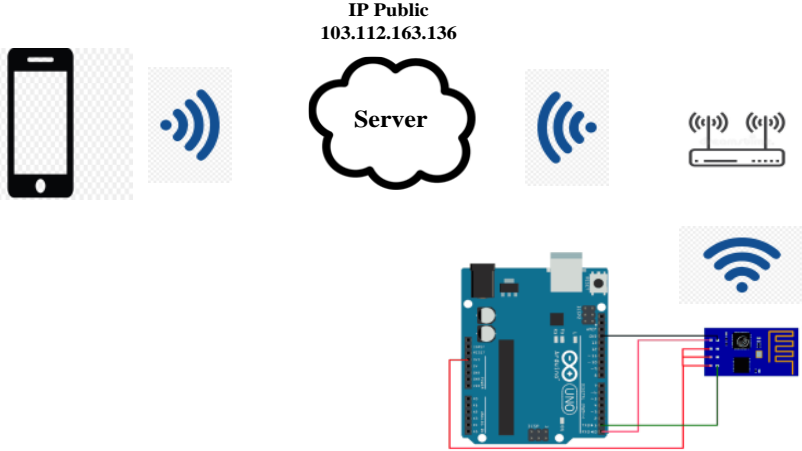

- Gambar 4. Jaringan Interkoneksi Sistem

Gambar 4 merupakan suatu interkoneksi dari beberapa perangkat digunakan dalam satu jaringan Interconnection Networking (Internet), untuk dapat saling berkomunikasi. Server pada sistem ini berfungsi untuk menunggu input yang masuk dari arduino maupun dari aplikasi android, server disini menggunakan IP Public Static sehingga proses pengiriman data dari arduino maupun aplikasi android hanya ditujukan pada satu alamat server yaitu IP Public tersebut. Setelah ada proses pengiriman data yang terjadi, server menampung input untuk sementara waktu lalu mengirimkannya ke dalam output yang masing-masing dituju. 


\section{Model Input dari Arduino ke Aplikasi Android}

Input yang dimaksud berupa perintah dari hasil penekanan tombol yang dilakukan oleh admin yang kemudian direspon oleh aplikasi Android, respon dari Aplikasi Android ini berupa pengiriman sebuah url melalui jaringan internet.

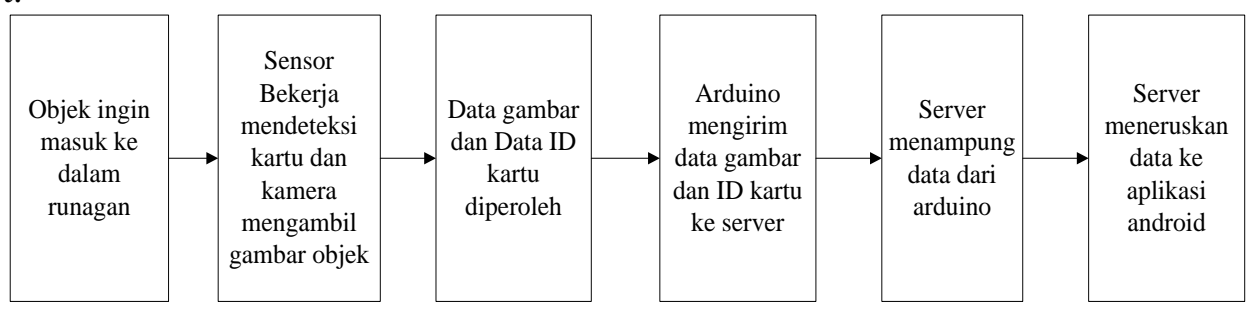

- Gambar 5. Blok diagram Model input dari arduino ke aplikasi android

Gambar 5 merupakan proses input dari Arduino ke aplikasi android, pada sistem ini dapat dilihat data yang dikirim berupa data gambar dengan format .jpg dan data nomor ID dari kartu RFID. Pada saat objek ingin masuk ke dalam ruangan, sensor RFID akan mendeteksi kartu yang ditempelkan oleh objek tersebut, di masingmasing kartu RFID sudah terdapat nomor identitas kartu yang tertanam didalamnya sehingga reader dari $R F I D$ dapat mebaca nomor identitas kartu tersebut, setelah nomor identitas didapat oleh sensor, langkah selanjutnya adalah reader tersebut juga akan menjadi pemicu untuk kamera dalam mengambil gambar objek tersebut sehingga menghasilkan data gambar dengan format .jpg. data yang diperoleh dari $R F I D$ dan kamera tersebut selanjutnya akan diteruskan oleh arduino kedalam server. seteleh server memperoleh data gambar dan nomor identitas kartu, lalu server meneruskan data tersebut ke dalam aplikasi android.

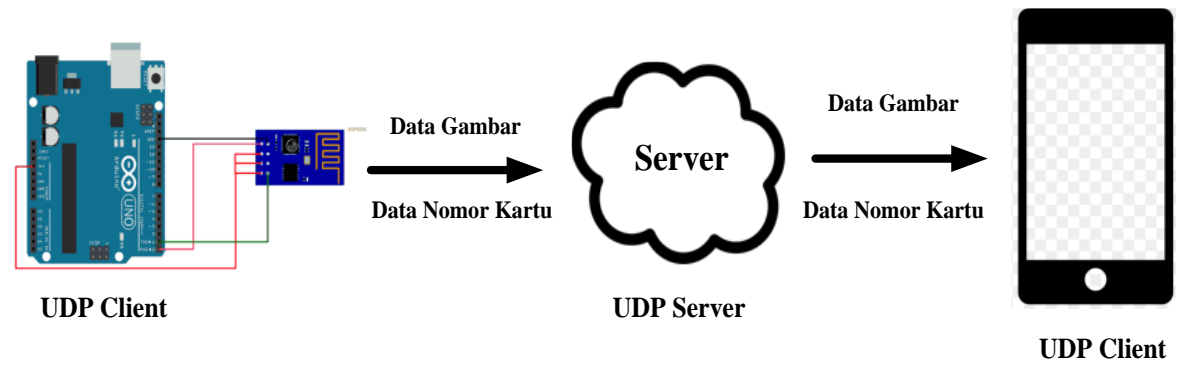

- Gambar 6. Blok diagram komunikasi antara client arduino ke android

Pada gambar 6 dapat dilihat proses pengiriman data menggunakan komunikasi jaringan UDP (User Datagram Protocol), komunikasi ini menggunakan sistem komunikasi half duplex, yang artinya komunikasi searah, dalam hal ini data nomor kartu di konversi menjadi satuan byte lalu dikirim ke dalam server dan diteruskan ke aplikasi android, begitu juga dengan data gambar yang berformat .jpg akan diteruskan ke dalam server dan aplikasi android.

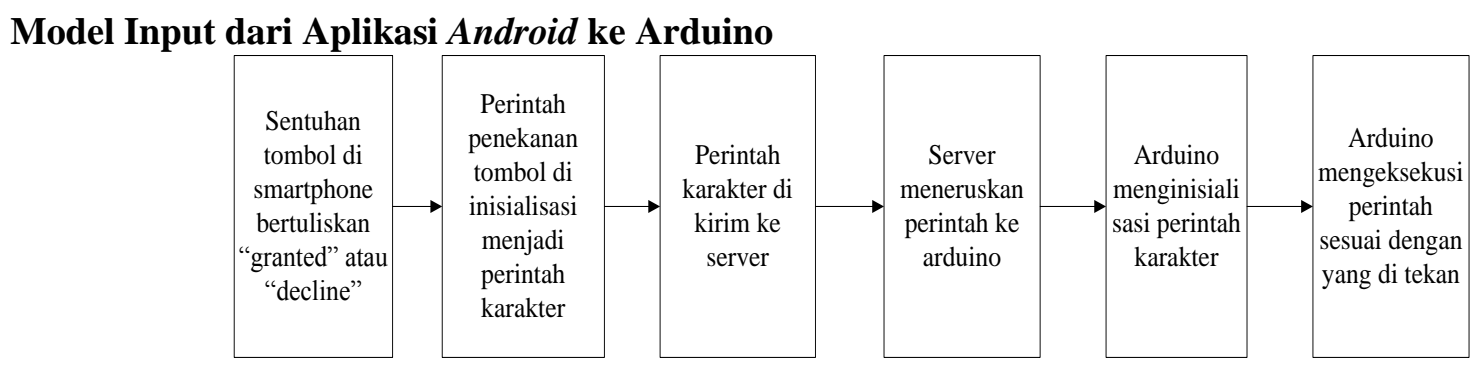

- Gambar 7. Blok diagram Model input dari aplikasi android ke arduino

Gambar 7 merupakan blok diagram model input pengiriman data dari aplikasi android ke dalam arduino, model input ini menjelaskan bahwa pada saat user menekan tombol perintah "granted" atau "decline", aplikasi android akan menginisialisasi perintah penekanan tombol tersebut sesuai dengan library yang ada di dalam program aplikasi android, sebagai contoh jika user menekan tombol "granted" maka perintah tersebut akan diinisialisasi oleh aplikasi android menjadi karakter huruf "ACK" karakter inilah yang nanti di kirimkan ke server dan diteruskan ke dalam arduino, di dalam library arduino karakter sudah di inisialisasi berfungsi untuk membuka pintu ruangan, sebaliknya juga dengan perintah tombol "decline" sudah di inisialisasi oleh aplikasi android menjadi karakter huruf "DND" karakter inilah yang nantinya akan diteruskan ke server lalu ke arduino dan di inisialisasi oleh library arduino yang berfungsi untuk menutup pintu. 


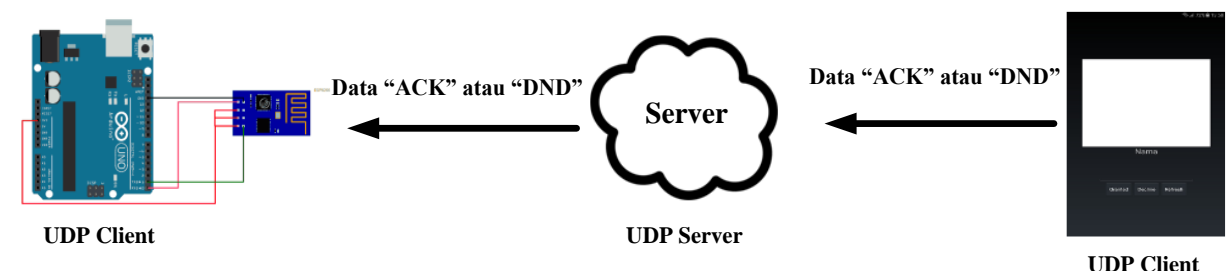

- Gambar 8. Blok diagram komunikasi antara client android ke arduino

\section{Model Proses}

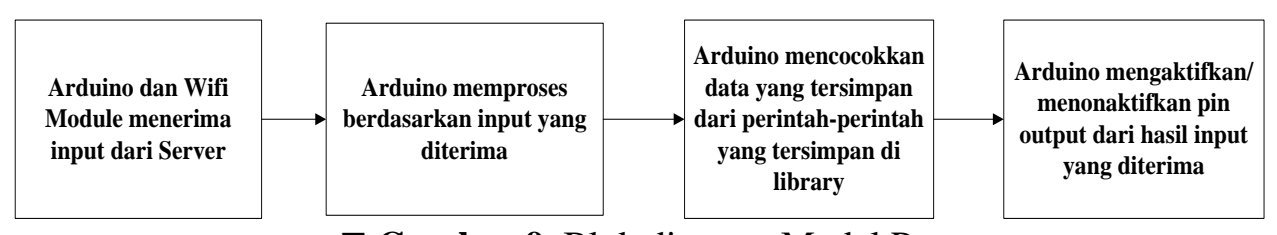

- Gambar 9. Blok diagram Model Proses

Gambar 9 merupakan gambaran proses dari sistem. Dengan cara kerja jika ada input yang dikirim Server ke dalam arduino maka arduino akan segera memproses input tersebut sesuai dengan input yang diterima, lalu setelah itu arduino akan mencocokkan atau memverifikasi input tersebut sesuai dengan library yang telah dibuat untuk sistem tersebut, jika input yang diterima oleh arduino sesuai dengan perintah-perintah yang ada di library, maka arduino akan mengaktifkan pin-pin output dari hasil input yang diterima.

\section{Model Output}

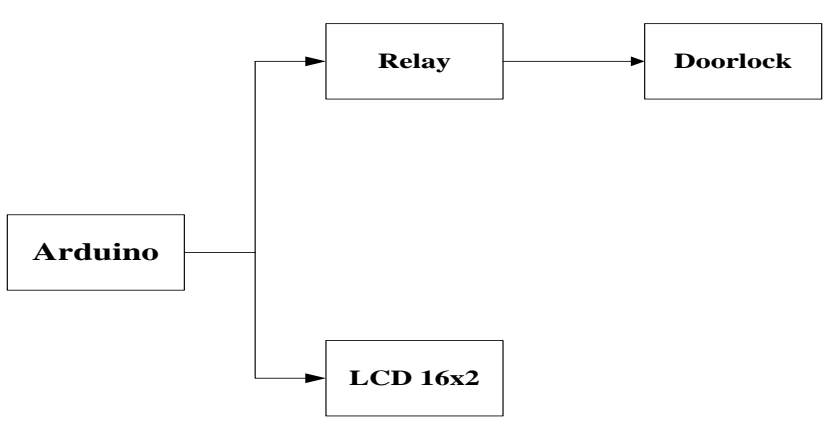

Gambar 10. Blok diagram Model Input

Pada gambar 10 merupakan model output pada sistem. Sistem kerja pada output ini adalah arduino akan memberikan atau memutuskan tegangan pada relay sesuai dengan input perintah yang diterima, sehingga relay akan melakukan membuka atau menutup selenoid door lock. Begitu juga dengan $L C D 16 \times 2$ akan mendapat sinyal perintah berupa tampilan di layar jika pintu dalam keadaan terbuka ataupun pintu dalam keadaan tertutup.

\section{Pengujian Jarak Antara Smartphone dan Access point}

\section{HASIL DAN PEMBAHASAN}

Tujuan pengujian ini adalah mengukur seberapa besar keberhasilan sistem berdasarkan jarak antara smartphone dengan access point. Setelah diadakan pengukuran kecepatan internet diperoleh hasil sebagai berikut, download 20 Mbps dan upload 4,59 Mbps.

Tabel 1. Pengujian jarak antara Access Point dengan Smartphone

\begin{tabular}{|c|c|c|}
\hline Jarak (Meter) & Kondisi & Pengujian Hassil \\
\hline 1 & Tidak ada halangan & Berhasil \\
\hline 5 & Tidak ada halangan & Berhasil \\
\hline 10 & Tidak ada halangan & Berhasil \\
\hline 15 & Terhalang pintu & Berhasil \\
\hline 20 & Terhalang pintu & Respon lama \\
\hline 30 & Terhalang pintu & Gagal \\
\hline Lantai 2 & Tidak ada halangan & Berhasil \\
\hline Lantai 2 & Terhalang pintu dan tembok & Berhasil \\
\hline 1 & Terhalang tembok & Berhasil \\
\hline 5 & Terhalang tembok & \\
\hline
\end{tabular}


Sistem Keamanan Ruangan Berbasis Internet Of Things Dengan Menggunakan Aplikasi Android

\begin{tabular}{|c|c|c|}
\hline 10 & Terhalang tembok & Berhasil \\
\hline 15 & Terhalang tembok & Berhasil \\
\hline 20 & Terhalang pintu dan tembok & Respon lama \\
\hline 25 & Terhalang pintu dan tembok & Respon lama \\
\hline 30 & Terhalang pintu dan tembok & Gagal \\
\hline
\end{tabular}

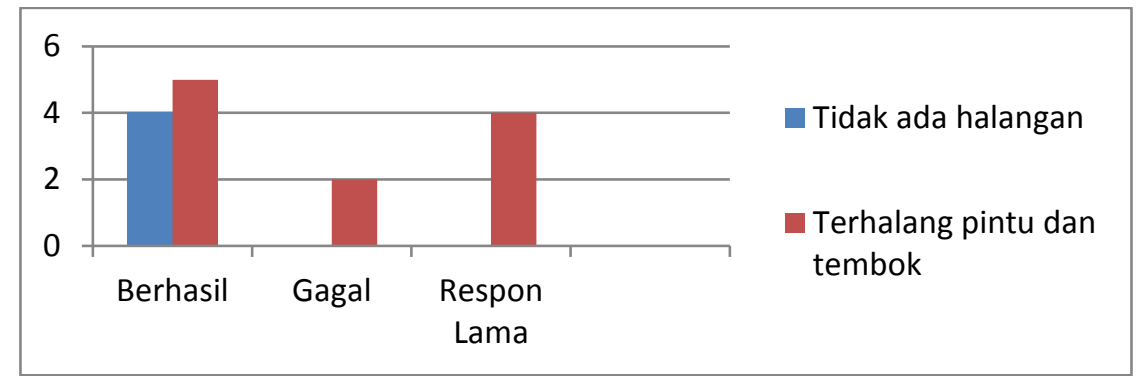

- Gambar 11. Grafik perbandingan tidak ada halangan dan terhalang

Setelah dilakukan pengujian pada table 1, perbandingan keberhasilan pengujian jarak antara smartphone dengan access point (Wifi) dengan tanpa halangan maupun dengan halangan maka diperoleh hasil seperti tampak pada gambar 11.

\section{Pengujian Waktu Jeda ESP8266}

Pengujian dilakukan dengan jarak 5 meter antara smartphone dan access point, Pengujian ini dilakukan untuk mengukur waktu jeda ketika data masuk kedalam aplikasi Android yang dikirim oleh modul Wifi ESP 8266, ketika kartu di scan oleh card reader.

Tabel 2. Pengujian waktu jeda

\begin{tabular}{|c|c|}
\hline Percobaan ke- & Waktu jeda (detik) \\
\hline 1 & 5.51 \\
\hline 2 & 5.36 \\
\hline 3 & 4.86 \\
\hline 4 & 5.89 \\
\hline 5 & 4.67 \\
\hline 6 & 5.01 \\
\hline 7 & 5.67 \\
\hline 8 & 5.23 \\
\hline 9 & 5.07 \\
\hline 10 & 6.03 \\
\hline
\end{tabular}

Setelah dilakukan pengujian waktu jeda sebanyak 10 kali. Maka diperoleh hasil yang terlihat pada tabel 2, dari tabel 2 maka dapat disimpulkan waktu rata-rata dari pengujian waktu jeda pada sistem ini adalah 5.33 detik.

\section{Pengujian Kamera VC0706}

Pengujian kamera VC0706 dilakukan untuk mengetahui keberhasilan kamera dalam mengambil gambar dan memasukannya kedalam aplikasi Android. Selain itu diuji juga sensitifitas modul RFID MIFARE RC522 sebagai pemicu kamera bekerja. Berikut adalah potongan tabel dari pengujian kamera.

Tabel 3. Pengujian kamera VC0706

\begin{tabular}{|c|c|c|}
\hline Percobaan ke- & File size (byte) & Status \\
\hline 1 & 3552 & Berhasil \\
\hline 2 & 3616 & Berhasil \\
\hline 3 & 3560 & Berhasil \\
\hline 4 & 3584 & Berhasil \\
\hline 5 & 3544 & Berhasil \\
\hline 6 & 3592 & Berhasil \\
\hline 7 & 3564 & Berhasil \\
\hline 8 & 3620 & Berhasil \\
\hline 9 & 3592 & Berhasil \\
\hline 10 & 3548 & Berhasil \\
\hline
\end{tabular}


- Tabel 4. Pengujian RFID Mifare RC522 RFID Mifare RC522 Trigger Test Jarak tempel kartu $0,5 \mathrm{~cm}$

Persentase keberhasilan $100 \%$

Dari tabel 3 dapat disimpulkan pengujian kamera VC0706 dilalkukan sebanyak 10 kali dengan persentase keberhasilan $100 \%$ dan rata-rata file size 3577,2 byte. Untuk pengujian sensitifitas RFID Mifare RC522 yang dilakukan sebanyak 10 kali dengan jarak temple kartu $0,5 \mathrm{~cm}$ mendapatkan persentasi keberhasilan sebanyak $100 \%$.

\section{Pengujian Jarak Antara Module Wifi Arduino dan Access Point}

Tujuan pengujian ini adalah mengukur seberapa besar keberhasilan sistem berdasarkan jarak antara Module Wifi Arduino dengan Access Point. Setelah diadakan pengukuran kecepatan internet diperoleh hasil sebagai berikut, download $20 \mathrm{Mbps}$ dan upload 4,59 Mbps.

Tabel 5. Pengujian Jarak Antara Module Wifi Arduino dan Access Point

\begin{tabular}{|c|c|c|}
\hline Jarak (Meter) & Kondisi & Pengujian Hassil \\
\hline 1 & Tidak ada halangan & Berhasil \\
\hline 5 & Tidak ada halangan & Berhasil \\
\hline 10 & Tidak ada halangan & Berhasil \\
\hline 15 & Terhalang pintu & Respon lama \\
\hline 20 & Terhalang pintu & Gagal \\
\hline 30 & Terhalang pintu & Berhasil \\
\hline Lantai 2 & Tidak ada halangan & Respon lama \\
\hline Lantai 2 & Terhalang pintu dan tembok & Respon lama \\
\hline 1 & Terhalang tembok & Respon lama \\
\hline 5 & Terhalang tembok & Respon lama \\
\hline 10 & Terhalang tembok & Respon lama \\
\hline 15 & Terhalang tembok & Gagal \\
\hline 20 & Terhalang pintu dan tembok & Gagal \\
\hline 25 & Terhalang pintu dan tembok & Gagal \\
\hline 30 & Terhalang pintu dan tembok & \\
\hline
\end{tabular}

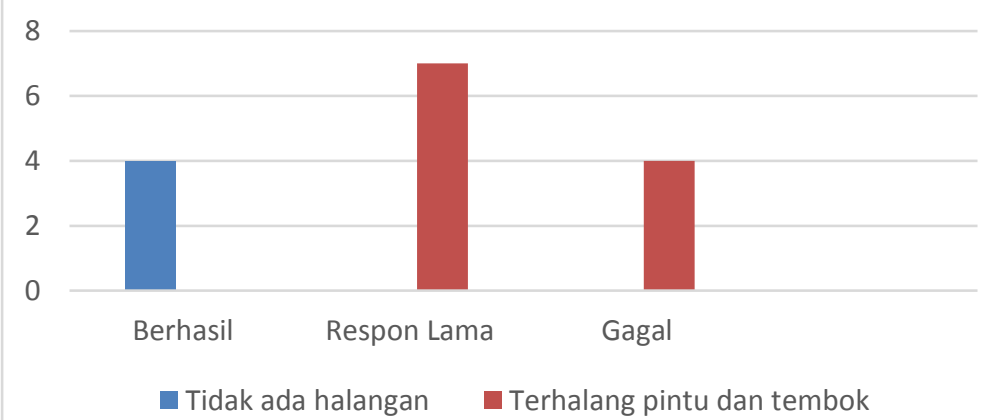

- Gambar 12. Grafik perbandingan tidak ada halangan dan terhalang

Setelah dilakukan pengujian pada tabel 5, perbandingan keberhasilan pengujian jarak antara smartphone dengan access point (Wifi) dengan tanpa halangan maupun dengan halangan maka diperoleh hasil seperti tampak pada gambar 12 .

\section{KESIMPULAN}

Kesimpulan yang didapat setelah melakukan pengujian dari sistem ini adalah :

1. Berhasil membuat suatu aplikasi dengan memanfaatkan internet untuk memantau dan mengendalikan suatu sistem keamanan yang ada diruangan.

2. Dengan adanya pemanfaatan dari internet ini maka admin dapat memantau dan mengendalikan sistem yang ada di ruangan tersebut dengan jarak yang jauh dan tidak terbatas. Pengujian yang telah dilakukan menunjukkan bahwa perintah yang dikirim dari aplikasi android kedalam server dapat mengendalikan 
sistem pengunci pintu yang terpasang menggunakan mikrokontroler dengan memanfaatkan aplikasi android yang dibuat di Droid Script.

\section{DAFTAR PUSTAKA}

[1] Ramadhan, A. S. Rancang Bangun Sistem Keamanan Rumah Berbasis Arduino Mega 2560. Teknik Informatika, Fakultas Ilmu Komputer, Universitas Dian Nuswantoro Vol 15 No 2, Mei 2016.

[2] M.Chamdun, A. F. Rochim, E.D. Widianto. Sistem Keamanan Berlapis Pada Ruangan Menggunakan RFID (Radio Frequency Identification) Dan Keypad Untuk Membuka Pintu Secara Otomatis. Jurnal Teknologi dan Sistem Komputer Vol 2 No 3, 2014.

[3] Panduardi, F. Wireless Smart Home System Menggunakan Raspberry pi Berbasis Android. Program Studi Teknik Informatika, Politeknik Negeri Banyuwangi Vol. 03 No. 01, Juli-Desember 2016.

[4] F. Susanto, M.N. Rifai, A. Fanisa. Internet of Things Pada Sistem Keamanan Ruangan, Studi Kasus Ruang Server Perguruan Tinggi Raharja. dalam Seminar Nasional Teknologi Informasi dan Multimedia, 2017.

[5] Sutopo, P. Sistem Informasi Eksekutif Sebaran Penjualan Kendaraan Bermotor Roda Dua Di Kalimantan Timur Berbasis Web. Jurnal Informatika Mulawarman Vol. 11 No. 1, Februari 2016.

[6] Hidayatulloh, S. Internet Of Things Bandung Smart City. Fakultas Teknik, Universitas BSI Vol.3, 2016.

[7] Putra, I. G. P. M. E. Monitoring Menggunaan Daya Listrik Sebagai Implementasi Internet of Things Berbasis Wireless Sensor Network. Teknologi Elektro Vol. 16 No.03, 2017. 